\title{
Richard BERNSTEIN, Filosofía y democracia: John Dewey
}

Ramón del Castillo (ed.) \& Alicia García Ruiz (trans.), Barcelona, Herder, 2010

\section{Núria Sara Miras Boronat}

\section{(2) OpenEdition \\ Journals}

Electronic version

URL: http://journals.openedition.org/ejpap/883

DOI: $10.4000 /$ ejpap.883

ISSN: 2036-4091

Publisher

Associazione Pragma

\section{Electronic reference}

Núria Sara Miras Boronat, "Richard BeRnsteIn, Filosofía y democracia: John Dewey», European Journal of Pragmatism and American Philosophy [Online], III-1 | 2011, Online since 01 July 2011, connection on 24 September 2020. URL : http://journals.openedition.org/ejpap/883 ; DOI : https://doi.org/10.4000/ ejpap.883

This text was automatically generated on 24 September 2020 .

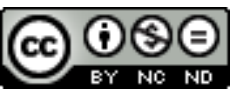

Author retains copyright and grants the European Journal of Pragmatism and American Philosophy right of first publication with the work simultaneously licensed under a Creative Commons AttributionNonCommercial-NoDerivatives 4.0 International License. 


\title{
Richard BERNSTEIN, Filosofía y democracia: John Dewey
}

Ramón del Castillo (ed.) \& Alicia García Ruiz (trans.), Barcelona, Herder, 2010

\author{
Núria Sara Miras Boronat
}

\section{REFERENCES}

Richard BERNSTEIN, Filosofía y democracia: John Dewey, Ramón del Castillo (ed.) \& Alicia García Ruiz (trans.), Barcelona, Herder, 2010

\section{Dewey and the Task before Us: The Making of the Democratic Experience}

1 This book review could also be entitled "John Dewey: Old and New," recalling a distant resemblance to one of the most well known books of Dewey, Individualism old and New (1930). But in this case the subject pursued under this title would be the development in the reception of John Dewey's work in the past century. This is a genuine hermeneutical reflection on the significance of one of the most important American intellectuals in the present day.

2 The following questions could belong to what in the European tradition of thought is called a "hermeneutical" approach. In which context is Dewey's philosophy to be understood? What could be the purpose of a collection of Richard Bernstein's essays from 1966 until 2010, i.e. from the old to the newest Bernstein's Dewey? What can the old Dewey say about the problems of democracy today? To answer the first question requires assuming a critical position towards our common philosophical past. The second question assumes a critical impasse between the old and new Dewey, and also the necessity to come back, in a reflexive way, to the origins from time to time. It means trying to break the distance but, at the same time, having to assume that a 
certain tension between past and present problems can never entirely be loosened. The hermeneutical question is thus bound to the practical interest of the common good. The answer to the third question demands not only a critical relationship to our shared past, but above all a compromise with the future: the task before us. And seeing the democracy as the task before us is exactly the clue that allows identifying the master key to Dewey's thought, old and new: making of democratic experience. That is the spirit, the ghost, that also crosses Bernstein's interpretation of Dewey.

3 In 1966 Bernstein shows his awareness of these considerations when he chooses a fragment of Dewey's essay "Philosophy and Civilization" (1927) as representative of Dewey's conception of philosophy: "The life of all thought is to effect a junction at some point of the new and the old, of deep-sunk customs and unconscious dispositions, that are brought to the light of attention by some conflict with newly emerging directions of activity. Philosophies which emerge at distinctive periods define the large patterns of continuity which are woven in effecting the enduring junctions of a stubborn past and an insistent future" (44). The interaction between immediate experience and critical distance, discretion and continuity, facts and values, the individual and the communal, theory and praxis, thought and action, is revisited in the 12 chapters that constitute the delicious introduction to Dewey's thought in 1966. The book is completed with two other essays first published in Bernstein's other books: "John Dewey on Democracy: the Task before Us" (from Philosophical Profiles. Essays in a Pragmatic Mode, 1986), and "John Dewey's Vision of Radical Democracy" (from The Pragmatic Turn, 2010). The book is attractive not only because it brings together all of Bernstein's accounts of Dewey but also because it makes them available to a broad Spanish-speaking audience, whose access to the 1966 essays had been otherwise impossible, as Amazon and similar sales had not existed until a few years ago. A third merit of the book is obviously in its presentation of the intellectual development of John Dewey, which would be especially valuable to those who are not necessarily acquainted with one of the most classical American pragmatists. But it is also a good opportunity for other Dewey scholars to initiate a dialogue concerning the importance of Dewey for the tradition of the American pragmatism in particular as well as the complex relation between philosophy and democracy in general.

4 A fourth appeal of the book, which may not be as obvious as those mentioned before, consists in the mode and style of the presentation. Rather than chronologically, Dewey's philosophy is introduced via different topics. The book contains the obligatory references to Dewey's life without being excessively biographical. An interesting philosophical discussion takes place without assuming a heavy metaphysical background. Bernstein's keeps a modest tone, achieving a lightweight introduction to such severe questions. The effect is seriously meritorious and the effect is a result of a conscious and delicate treatment of Dewey's deepest philosophical concerns. And this is of course the most Deweyan way to attend his conception of philosophy, which requires a combination of "modesty and courage." Attending to his conception is the "only way I know of," writes Dewey, "in which the philosopher can look his fellow man in the face with frankness and with humanity."

Dewey's philosophical themes were rich and various, reaching the variety of spheres of human life, from psychology to the nature of scientific inquiry, from arts to values, and from education to the ups and downs of political life. A short explanation of Dewey's main contributions to philosophy can be helpful in showing the complexity of his 
thought. The first and primary concern of the man Dewey could be the vision of philosophy as a critical and reconstructive task. This is true if we decide to enter in a reflexive dialogue with the past philosophical traditions which may nowadays sound trivial, since making history of philosophy is part of doing philosophy. However, when Dewey started doing philosophy, he could have reflected on any American philosophical tradition. As Bernstein points out, the origins of Dewey's philosophy are an imprint of the conjunction between the philosophies of Hegel and Darwin. This is in fact a double consideration of human reality as a dynamic reality, called either Geist or Nature. This is a world-view that contrasts strongly with the quiet realism or the sober transcendental idealism. For realism, the objects stay as such, isolated and exposed to our senses waiting to be discovered. For transcendental idealism, the Ding-an-sich may remain a mystery, but we can keep ourselves satisfied by seeing it through the conceptual system projected by the categories of human understanding.

In some restricted sense, realism and transcendental idealism may admit surprises and adventures. But this sense is far away from a world of relations and transactions, in which the whole composition remains constantly changing. It forces one into a state of permanent reconstruction of his experience, not because the discretional elements of experience wait for its essence to be perceived or revealed, but because what we experience is a constantly changing reality. Experience itself is complex in how it is part of a structure that involves a whole framework beyond the instant act of perception, recalling experiences of the past and looking forward to the future. As Bernstein shows from the first chapters, the most exciting find of Dewey's theoretical philosophy is the discovery of another concept of experience, which is opposed to what Dewey called "the orthodox description of the experience" (98). The unorthodox description of the experience is an attempt to overcome the classical dualisms in epistemology (experience vs. reflection, subjectivity vs. objectivity, activity vs. passivity) that Dewey considers to be misleading. In this way, experience and nature could not be understood as two opposing realities since all experience takes place within nature. Nature must thus be redefined as a "variety of transactions" (119). Reconsidering and reconstructing the complex unity of experience allows Dewey to state that "every reaction is adventure, risk," for every living being compelled to give a response to its environment (111). Following this argument it is easier to notice the coherence between Dewey's theoretical philosophy and his philosophy of science. Dewey understands scientific inquiry as the reconstruction of an undetermined, obscure, confused or problematic situation and, in addition, finding the solution. Every situation is a preliminary stage for future problems whose specificity cannot be known to ourselves in the present and depends on unimaginable situations arising from our actual perspective. We not only have natural history but nature also has its own history.

7 Stressing the continuity of the experience within nature finds its counterpart in Dewey's definition of values. Dewey takes the divorce between science and values as one of the most dangerous illness of our times (152). The naturalist fallacy between facts and values since Hume is causing more damages to our pursuit of a good life than what we could suspect: moral life is also a subject of inquiry, of choosing the right ends, of experimenting by using imagination with hypothetical possibilities of action, in an analogous way as we do in the natural science. This is without a doubt one of the most controversial points in Dewey's philosophy. Bernstein places Dewey in the Aristotelian tradition: values do not exist in an independent realm of pure ideas. They are relative 
to the concrete situation and depend on a complex process of deliberation. Values ratified by deliberation deserve the special name of "consummatory experiences" (154). It could be interesting in this point to figure out a connection between Dewey's consummatory experiences and Dilthey's Erlebnisse or Husserl's Lebenswelt. They are all a means to underline the continuity of experience between the spheres and times of human life.

8 The moral philosophy of Dewey is summarized in a few traits. One could think that Dewey's formula for the dealing with practical conflicts is relatively easy: Reasoning + Experience $=$ Practical Intelligence. But that would be a false presumption. Becoming an intelligent, experienced individual, means learning to make the correct decisions and takes a lot of work. It requires training in basic habits and dispositions that have to be embodied in our community. Our commitment is not fulfilled until we take the forging of a certain form of life. Our personal task should consist in embracing the unique form of life that promotes equally common goods and individual development. Here we arrive to the cornerstone of Dewey's philosophy: the school as the labor of our democracy. Dewey's "pedagogic creed" converges with Dewey's "democratic faith."

What is striking of Bernstein's reading of Dewey is how soft this step from theoretical inquiry to practical reason seems to be. This is a very delicate step, showing the bridges where Kantian philosophy makes a sharp division. But this is not affirmed in the sense of a naive moral realism, but more in the spirit of "fallibilistic humanism" (236) that Bernstein appreciates in Dewey. The continuity of the experience, whether in facts or values, becomes a very important topic in Bernstein's latest reflections. Perhaps is he turning more and more to William James and the vision of an integral life in a Pluralistic Universe? A pluralistic world, as James stated, is more a federal republic than an empire or a kingdom. Bernstein revisits James in The Pragmatical Turn in a radicalized way, exploring the ethical consequences of his cosmological pluralism, which can no longer be ignored. Or it might be true also the other way round in Dewey's eyes: "Pragmatism thus has a metaphysical implication. The doctrine of the value of consequences leads us to take the future into consideration. And taking this into consideration of the future takes us to the conception of a universe whose evolution is not finished, of a universe which is still, in James' term, 'in the making,' 'in the process of becoming,' of a universe, up to a certain point still plastic." 2 Being a "naturalistic humanist" means that one abandons the belief that "nature is an indifferent, dead mechanism."

"A pluralistic universe is open to both tragedy and melioration," writes Bernstein about James. Dewey agrees with him in the chapter of Experience and Nature called "Existence as Precarious and as Stable" noting that: "Comedy is as genuine as tragedy." We cannot postulate a direct or univocal relationship between theory and praxis of the philosopher's thought, but certainly we can identify theoretical tendencies that make some practical virtues more "probable." The detractors of pluralism argue that pluralism is a philosophical position claiming for respect for all sorts of faiths and beliefs but it cannot give any strong theoretical argument to support its own compromise with the democratic credo. Maybe as pluralists we should always maintain some sort of "bicameral disposition," an unsolved tension between our compromise with our personal existential faith and an opening to the existential compromises of others. ${ }^{5}$ This is another reason to see democracy as a task before us, a task that demands more radicalization, because according to Dewey: "The end of democracy is a 
radical end. For it is an end that has not been adequately realized in any country at any time" (247).

11 This pragmatist and pluralistic approach has its weaknesses, of course. Bernstein recognizes several big Achilles' heels in Dewey's pragmatism: the analysis of concrete problems, the supplying of means to overcome the contradictions of democratic life, and the institutional analysis, among others. Dewey also admitted that our pluralistic world is something different to the pluralism he ascribes to Aristotle: "His plurals fall however, within a grammatical system, to each portion of which a corresponding cosmic status is allotted. Thus his pluralism solved the problem of how to have your cake and eat it too, for a classified and hierarchically ordered set of pluralities, of variants, has none of the sting of the miscellaneous and uncoordinated plurals of our actual world."' But it would be in Dewey's spirit to allow open paths for further inquiry about how to improve our conditions of life. In the theory, some of his more important contributions were to denounce the misleading images that held us captive, to speak in a Wittgensteinian language: the epistemological metaphor of the spectator which advances what Bernstein will later call the "Cartesian anxiety." The anxious search for ultimate foundations returns to philosophy under a plurality of forms. And the best strategy is not a confrontation with the enemy but a dialogical deconstruction of his seductive power and the emphasis of points for possible mutual understanding. Bernstein does this in two rounds. In 1966 against the most influent philosophical tendencies of the moment: phenomenology, philosophy of science, linguistic analysis and existentialism. In 1986 he deals with the false dichotomy between liberalism and communitarianism. In both cases the use of Dewey's remedy has a healthy, comforting effect.

Perhaps this effect explains partially why European philosophers care about American pragmatism, besides being, as the American classical pragmatist has seen it, a further development of philosophy with European roots. ${ }^{8}$ In some sense, being a Pragmatist is like being an existentialist, assuming tragedy and improvement as human possibilities, but it is certainly more "hygienic" that Sartre's nausée and sees human commitment not as a vain passion but as an enriching conquering of horizons. It allows being an individual without neglecting the civic compromise with the community. This community is not the abstract formal condition of Kantian categorical imperative. It is concrete and present. It allows being critical but still trusting, in contrast to skepticism. And requires a more critical use of divisions, names and labels, while stresses more continuities and relationships, transactions and constellations. It might be the philosophy that, following a well-known Hegelian sentence, captures its epoch in thoughts.

13 The introduction of Ramón del Castillo shows in a diaphanous way the advantages of these hermeneutical and pragmatist approaches to philosophy. He can present briefly what is at play between the conflicting narratives of contemporary American thought. He offers what a good introduction should offer to the curious ones who are new to Dewey: (1) a cultural and historical portrait of the rising, fall and rehabilitation of the intellectual figure of John Dewey at the beginning of the 20th century, which in turn, explains (2) what made Bernstein's approximation to Dewey so surprising and interesting by that time, (3) that his first dealing with Dewey can be proven for its continuity and its revision in the brief two new translated essays, and (4) what role Dewey plays in Bernstein's philosophical career as a pragmatist himself. The 
translation of Alicia García Ruiz has a wonderful cadence that gently accompanies the rhythm of the thoughts presented. Two recommended bibliographies include one from Richard Bernstein in 1966 and another by Ramón del Castillo and Alicia García in 2010. This informs the reader about the movements and the gaps within contemporary Pragmatism in this time interval.

We began with the claim that there is a possible hermeneutic and practical account of Dewey, which means nothing less than saying Dewey could help us to cope with the present problems of democracy. Bernstein already has an answer: what we need for the problems of democracy is more democracy. I would like to end this presentation of Dewey, with a reflection of Gadamer, a long-life friend of Richard Bernstein and the Founding Father of the philosophical hermeneutics. He said, that all human experience is part of an endless conversation. A conversation, as Richard Bernstein sees, is in its essence a thrilling human enterprise: "A conversation can be civilized, illuminating, intelligent, revealing, exciting. Truth may be relevant to a conversation, but so can many other things, and a conversation is not to be thought of as a disguised inquiry into truth or the discovery of foundations." 9 The tradition we belong to can also be seen as a conversation with all the voices in both the past and the present, merging into a complex polyphony. If we think of our traditions as conversations and our intellectuals as louder voices speaking from inside the community, we can also think of the philosopher as one who is not dead when he speaks his last word, but when his or her voice disappears of the conversation. And this is our decision and responsibility, to decide what to make in the future with Dewey, keeping in mind the old and the new.

\section{NOTES}

1. Dewey J., (1984), "Philosophy and Civilization," in The Later Works, 1925-1928, vol. 3, Carbondale, Southern Illiniois University Press, 10.

2. Dewey J., (1984), "The development of American Pragmatism," in The Latter Works, 1925-53, vol. 2, Carbondale, Southern Illinois University Press, 13.

3. Dewey J., (1984), "Experience and Philosophic Method," in The Latter Works, 1925-53, vol.1, Carbondale, Southern Illinois University Press, 28.

4. Dewey J. (1984), "Existence as Precarious and as Stable," in The Latter Works, 1925-53, vol.1, Carbondale, Southern Illinois University Press, 45.

5. Connolly W. E., (2005), Pluralism, Durham, Duke-University Press, 1.

6. Dewey, J. (1984), "Existence as Precarious and as Stable," in The Latter Works, 1925-53, vol.1, Carbondale, Southern Illinois University Press, 48.

7. Bernstein, R., (1983), Beyond Objectivism and Relativism, Philadelphia, University of Pennsylvania Press, 16.

8. Dewey J. (1984), “The development of American Pragmatism," in The Latter Works, 1925- 1953, vol. 2, Carbondale, Southern Illinois University Press, 19.

9. Bernstein R., (1985), "Philosophy in the Conversation of Mankind," in Hollinger R. (ed.), Hermeneutics and Praxis, Notre Dame, University of Notre Dame Press, 75-6. 


\section{AUTHORS}

\section{NÚRIA SARA MIRAS BORONAT}

FECYT (Spain) / University of Leipzig (Germany)

nsmira[at]ub.edu 